\title{
METABOLISM OF TERBUTALINE IN MAN AND DOG
}

\author{
D.S. DAVIES, C.F. GEORGE, ELAINE BLACKWELL, M.E. CONOLLY \& C.T. DOLLERY \\ M.R.C. Clinical Pharmacology Research Group, \\ Department of Clinical Pharmacology, Royal Postgraduate Medical School, London W.12
}

1 The metabolism of terbutaline (1-(3,5-dihydroxyphenyl)-2-tertiarybutylamino-ethanol), a drug which acts selectively on $\beta_{2}$-adrenoceptors has been studied in man and dog.

2 The sulphate conjugate of terbutaline was the only metabolite identified in plasma or urine from humans or dogs given the drug either orally or intravenously. We have confirmed that terbutaline, a resorcinol derivative, is not a substrate for catechol-0-methyl transferase in man or dog.

3 Metabolism of terbutaline was dependent upon the route of administration in man, but not in dog. In man, oral terbutaline was largely conjugated whereas drug administered intravenously appeared largely unchanged in urine.

4 Conjugation of oral terbutaline, which probably occurred during the 'first-pass' through the gut wall or liver, was less than oral isoprenaline. This may explain why the poorly absorbed terbutaline is a more effective oral bronchodilator than isoprenaline, even though the latter drug is completely absorbed following oral dosing.

\section{Introduction}

A number of $\beta$-adrenoceptor stimulant drugs are widely used in the treatment of bronchial asthma. Drugs such as isoprenaline stimulate both bronchial $\left(\beta_{2}\right)$ and cardiac $\left(\beta_{1}\right)$ adrenoceptors and hence give rise to unpleasant side effects such as palpitations. This led to a search for drugs which act selectively on $\beta_{2}$-adrenoceptors; terbutaline (1 - (3,5 - dihydroxy phenyl) -2-tertiarybutylaminoethanol) is a drug which has been shown to act selectively on $\beta_{2}$-adrenoceptors (Bergman, Persson $\&$ Wetterlin, 1969). The metabolism of catecholamine-like bronchodilator drugs such as isoprenaline has been studied in animals (Hertting, 1964; Conway, Minatoya, Lands \& Skekosky, 1968) and in man (Conolly, Davies, Dollery, Morgan, Paterson \& Sandler, 1972). Isoprenaline is 0-methylated by catechol-0-methyl transferase (COMT) and conjugated with sulphuric or glucuronic acids. The amount of 0 -methylation and conjugation is very dependent on the route of administration as is the pharmacological action. Since terbutaline is a resorcinol and therefore not a substrate for COMT (Persson \& Persson, 1972) it was of interest to study its metabolism.

\section{Methods}

Compounds

Terbutaline-7- $\left[{ }^{3} \mathrm{H}\right]$ hydrobromide $(3 \mathrm{mCi} / \mathrm{mg})$ was supplied by the Research Laboratories of $\mathrm{AB}$
Astra, Sodertalje. It was diluted with nonradioactive drug to prepare doses of the required specific activity.

\section{Human studies}

The patients studied were hypertensives over the age of 40 years attending Hammersmith Hospital and their informed consent was obtained. Studies were done in the supine position and heart rate was monitored with an ECG triggered rate meter.

Three patients were given $100 \mu \mathrm{g}(50 \mu \mathrm{Ci})$ of terbutaline intravenously and four patients received oral doses of 5-10 mg (50 to $250 \mu \mathrm{Ci}) 2 \mathrm{~h}$ after a light breakfast. Blood samples were taken at appropriate time intervals after dosing and immediately centrifuged. Plasma samples were stored at $-20^{\circ} \mathrm{C}$ until they were analysed. Complete collections of urine and faeces were obtained for 3-8 days and stored at $-20^{\circ} \mathrm{C}$.

\section{Dog studies}

Six mongrels of either sex, weighing 12-24 kg were anaesthetized with thiopentone and pentobarbitone. The seventh dog, a greyhound weighing $24.5 \mathrm{~kg}$, was studied in the conscious state.

Heart rate was monitored with an ECGtriggered rate meter, and blood pressure was measured in the anaesthetized dogs using a Consolidated Electrodynamics pressure transducer 
attached to a PE 160 polythene catheter inserted $15 \mathrm{~cm}$ into one femoral artery.

Intraduodenal administration. In three dogs the abdomen was opened through a midline incision and the duodenum located. A soft rubber catheter was then inserted through the wall of the second part of the duodenum and secured with a purse string suture. The dose of $2 \mathrm{mg}$ terbutaline $/ \mathrm{kg}$ was given by slow injection down this catheter in a volume of $20 \mathrm{ml}$. Blood samples were taken and urine collected for $2-8 \mathrm{~h}$ after dosing. Bile was collected by cannulation of the common duct in one animal.

In the conscious dog a dose of $90.5 \mu \mathrm{g}$ $(271 \mu \mathrm{Ci})$ was given via a gastric tube. Blood and urine were collected in this animal for $24 \mathrm{~h}$ after dosing.

Intravenous administration. Four dogs were studied following a dose of 2.3 to $18.65 \mu \mathrm{g} / \mathrm{kg}$ of terbutaline which was given as a single rapid injection. Blood samples were taken at frequent time intervals up to $3.75 \mathrm{~h}$ after dosing and urine was collected from an indwelling catheter.

\section{Analytical procedures}

Radioactivity in plasma, urine and bile was measured in a Packard Liquid Scintillation Spectrometer in Instagel scintillator fluid. Daily faecal samples were homogenized and diluted to $1,000 \mathrm{ml}$ and $0.1 \mathrm{ml}$ aliquots were combusted in plastic bags in an atmosphere of oxygen (Gupta, 1968). The tritiated water formed was dissolved in scintillator fluid injected into the bag after combustion and an aliquot was counted. All counts were corrected for quenching using the external radioactive source of the scintillation spectrometer.

Terbutaline in plasma and urine was extracted with ethyl acetate. One $\mathrm{ml}$ of plasma or urine was diluted with $1 \mathrm{ml}$ of $2 \mathrm{~N} \mathrm{NH}_{4} \mathrm{OH}$ following addition of a few $\mathrm{mg}$ of dithionite. The aqueous phase was extracted with $15 \mathrm{ml}$ of ethyl acetate by mixing on a Vortex mixer for 1 minute. After centrifugation a $10 \mathrm{ml}$ aliquot of the ethyl acetate was counted. Recovery of terbutaline from plasma and urine was $66.7 \pm 9.2 \%$ ( 2 S.D., $n=13$ ). The identity of material in the ethyl acetate extract was confirmed by thin layer chromatography.

Radioactivity in the faeces was identified as follows. A sample of faecal homogenate was freeze-dried. The resultant powder was then extracted with methanol in a Soxhlet thimble for 6 hours. The extract was taken to dryness, and an aqueous solution of the residue was made. This was then extracted with ethyl acetate as described

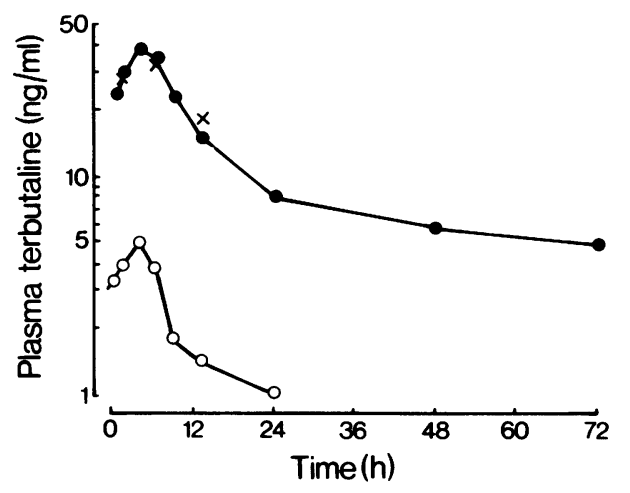

Fig. 1 Radioactivity in plasma following oral administration of $\left[{ }^{3} \mathrm{H}\right]$-terbutaline to $\operatorname{man}(130 \mu \mathrm{g} / \mathrm{kg}$; subject 4). (๑), total radioactivity; (0), free terbutaline; $(x)$ free terbutaline after hydrolysis.

above for plasma and urine. The ethyl acetate extract was chromatographed on cellulose plates using butanol: glacial acetic acid: water (w/v $4: 1: 1$ ). The area of radioactivity was scraped off and extracted with methanol. This was examined by combined gas chromatography-mass spectrometry after treatment with N,0-bis (trimethylsilyl) acetamide.

\section{Hydrolysis}

Hydrolysis of suspected conjugates of terbutaline was carried out chemically and enzymatically. For acid hydrolysis, urine or plasma samples were adjusted to $\mathrm{pH} 0.9$ with $10 \mathrm{~N} \mathrm{HCl}$ and refluxed for 20 minutes. For enzymatic hydrolysis $1 \mathrm{ml} \mathrm{sam}$ ples of plasma or urine were adjusted to $\mathrm{pH} 5.5$ with acetate buffer and were incubated at $37^{\circ} \mathrm{C}$ for $15 \mathrm{~h}$ with arylsulphatase/ $\beta$-glucuronidase $(0.26$ units sulphatase with 0.52 units $\beta$-glucuronidase) or $\beta$-glucuronidase (5.8 units). Following hydrolysis terbutaline was measured as described above for plasma and urine.

\section{Results}

Following doses of $5 \mathrm{mg}$ to subject 1 and $10 \mathrm{mg}$ to subjects 2,3 and 4 , the respective maximum plasma total radioactivity reached peaks equivalent to $29,45,35$, and $37 \mathrm{ng}$ terbutaline/ml plasma. These levels were reached at $1,2,1$ and $4 \mathrm{~h}$ respectively. Thereafter the radioactivity declined biphasically as is shown for subject 4 (Figure 1 ). The levels of unchanged terbutaline in plasma were below the limits of detection for the first three subjects but in subject 4 , who received $250 \mu \mathrm{Ci}$, a 
peak of $4.9 \mathrm{ng} / \mathrm{ml}$ was reached at 4 hours. Free terbutaline did not account for more than $15 \%$ of the total radioactivity in any of his samples and usually was less than 10\% (Figure 1). However, after hydrolysis with acid, levels of free terbutaline were increased and accounted for more than $90 \%$ of the total radioactivity (Figure 1). No increase in heart rate was detected in any of the subjects.

From $59.4-78.5 \%$ of the dose of radioactivity was recovered in, urine and faeces in 3 to 8 days (Table 1). Radioactivity in urine accounted for $22.5-25.7 \%$ of the dose; $5.2-6.35 \%$ of the dose was excreted in urine as unchanged terbutaline. Acid hydrolysis of urine samples showed that the remainder of the activity was a conjugate of terbutaline. Hydrolysis with enzymes showed that the suspected conjugate was readily split by aryl sulphatase but not by $\beta$-glucuronidase (Table 2 ). Chromatography of samples of urine before and after hydrolysis confirmed that unchanged terbutaline was released during hydrolysis.

A large proportion (35.6-5.6.0\%) of the administered radioactivity was eliminated in the faeces. This was almost totally recoverable from freeze dried faecal homogenate as unchanged terbutaline (Table 1). Radioactivity extracted from faeces was co-chromatographed with authentic terbutaline on thin layer plates. No other radioactive bands were detected. The trimethylsilyl derivative of the radioactive material scraped from the thin layer plates had the same gas chromatographic retention time as authentic terbutaline. Mass spectra recorded on this material contained fragments in common with the trimethylsilyl derivative of terbutaline.

\section{Intravenous administration to man}

Doses of $100 \mu \mathrm{g}$ intravenously produced peak plasma concentrations of terbutaline of $3-8 \mathrm{ng} / \mathrm{ml}$. Radioactivity declined biphasically as is shown for one patient in Figure 2. Heart rate increased to 10 beats/min above resting and rapidly returned to baseline values. No change in heart rate was detected in the other two subjects.

Analysis of plasma showed that unchanged terbutaline accounted for greater than $85 \%$ of the radioactivity over the first $60 \mathrm{~min}$ after dosing.

From $78.4-85.7 \%$ of the radioactivity was excreted in urine over a period of $91-120 \mathrm{~h}$ (Table 3). A small percentage (2-3\%) of activity was recovered from the faeces. Extraction of urine

Table 1 Excretion of metabolites following oral administration of [ $\left.{ }^{3} \mathrm{H}\right]$-terbutaline to man

\begin{tabular}{|c|c|c|c|c|c|c|c|}
\hline \multirow[t]{3}{*}{ Subject } & \multirow[t]{3}{*}{ Dose (mg) } & \multirow[t]{3}{*}{ Time (h) } & \multicolumn{5}{|c|}{ \% of dose recovered in: } \\
\hline & & & \multicolumn{3}{|c|}{ Urine } & \multicolumn{2}{|c|}{ Faeces } \\
\hline & & & $\begin{array}{c}\text { Total } \\
\text { radioactivity }\end{array}$ & $\begin{array}{c}\text { Free } \\
\text { terbutaline }\end{array}$ & $\begin{array}{l}\text { Conjugated * } \\
\text { terbutaline }\end{array}$ & $\begin{array}{c}\text { Total } \\
\text { radioactivity }\end{array}$ & $\begin{array}{c}\text { Free } \\
\text { terbutaline }\end{array}$ \\
\hline 1 & $5(50 \mu \mathrm{Ci})$ & 70 & $23.8[20]$ & 6.3 & 16.1 & 35.6 & - \\
\hline 2 & $10(50 \mu \mathrm{Ci})$ & 144 & $22.5[19]$ & 5.2 & 14.7 & 45.5 & 45.5 \\
\hline 3 & $7.5(50 \mu \mathrm{Ci})$ & 185 & $25.7[20]$ & 6.35 & 19.0 & 52.6 & 47.3 \\
\hline 4 & $10(250 \mu \mathrm{C} i)$ & 96 & $22.5[19]$ & 5.2 & 17.2 & 56.0 & 48.7 \\
\hline
\end{tabular}

* By difference following acid hydrolysis.

[ ] \% dose recovered in 24 hours.

Table 2 Acid or enzyme hydrolysis of urine from patients receiving oral $\left[{ }^{3} \mathrm{H}\right]$-terbutaline (for dose see Table 1)

Subject Total $\left[{ }^{3} \mathrm{H}\right]$

$(\mathrm{dpm} / \mathrm{ml})$

$\begin{array}{rr}1 & 6030(100 \%) \\ 2 & 3222(100 \%) \\ 3 & 8785(100 \%) \\ 4 & 23292(100 \%)\end{array}$

Before hydrolysis

$1574(26 \%)$

741 (23\%)

2196 (25\%)

$5376(23 \%)$

\section{$\left[{ }^{3} \mathrm{H}\right]$ extractable as free terbutaline $(\mathrm{dpm} / \mathrm{m} /)$}

Acid hydrolysis

$5668(94 \%)$

2835 (88\%)

8780 (99\%)

23175 (99\%) $\beta$-glucuronidase

1888 (31\%)

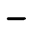

$5764(24 \%)$
Aryl sulphatase/ß-glucuronidase $6802(112 \%)$

$24272(104 \%)$

(. ) \% total $\left[{ }^{3} \mathrm{H}\right]$ extracted as terbutaline. 


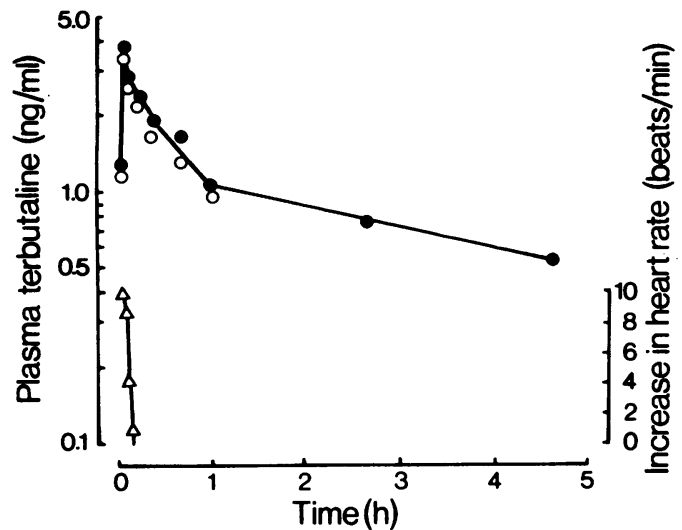

Fig. 2. Radioactivity in plasma and change in heart rate following intravenous administration of $\left[{ }^{3} \mathrm{H}\right]$ terbutaline to man $(1.0 \mu \mathrm{g} / \mathrm{kg}$; subject 5$)$. ( $(\bullet)$, total radioactivity; $(0)$, free terbutaline; $(\Delta)$, change in heart rate.

before and after hydrolysis showed that $52.1-60.4 \%$ of the dose was excreted as unchanged drug with $4.0-19.4 \%$ as sulphate conjugate. In all urine samples a proportion of the radioactivity remained unidentified (Table 3 ).

Intraduodenal and intragastric administration to dogs

Peak plasma levels of $300-652 \mathrm{ng} / \mathrm{ml}$ were achieved at $45-57 \mathrm{~min}$ in the first two intraduodenal studies (Figure 3). In the third study there was a fall in the plasma radioactivity after the first $10 \mathrm{~min}$, which coincided with a sharp drop in the renal, and presumably other splanchnic bed, blood flow. Blood flow in the renal artery, which was monitored with an electromagnetic flow meter, was restored by giving 2 litres of saline i.v. and thereafter the plasma radioactivity began to rise
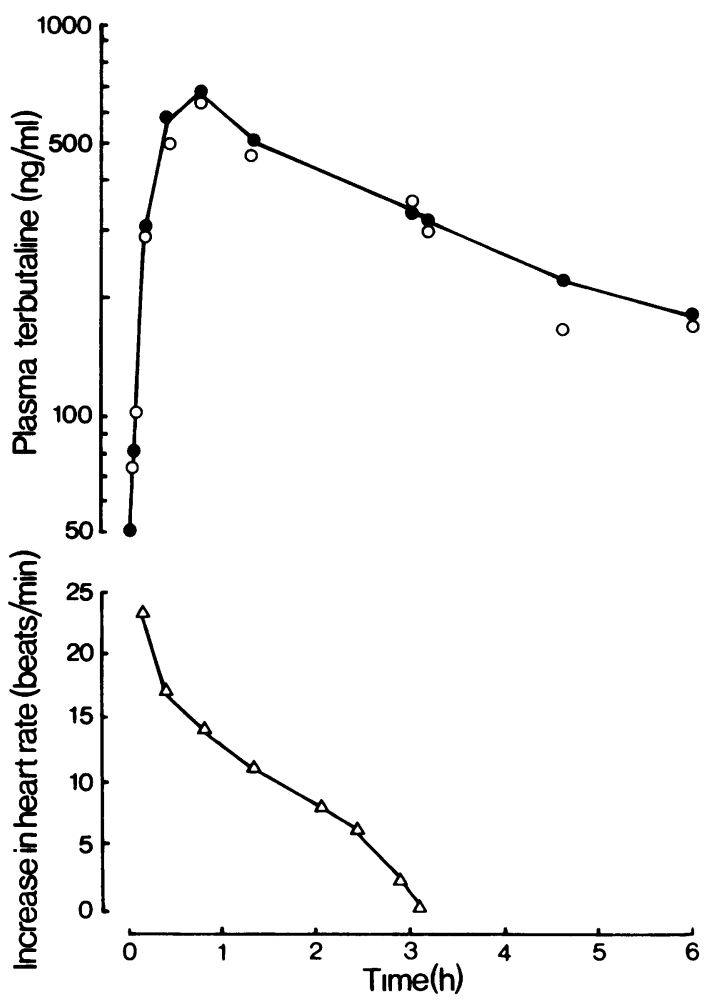

Fig. 3 Radioactivity in plasma and change in heart rate following intraduodenal administration of $\left[{ }^{3} \mathrm{H}\right]$-terbutaline to the dog $(2 \mathrm{mg} / \mathrm{kg}$; anaesthetized dog 2). (๑), total radioactivity; (0), free terbutaline; $(\Delta)$, change in heart rate.

again, finally reaching a peak equivalent to $740 \mathrm{ng}$ terbutaline/ml at 4 hours. Analysis of plasma samples from the three dogs showed that unchanged terbutaline accounted for more than $90 \%$ of the radioactivity (Figure 3 ).

Table 3 Excretion of metabolites following intravenous administration of $\left[{ }^{3} \mathrm{H}\right]$-terbutaline to man

\begin{tabular}{cccccccc}
$\begin{array}{c}\text { Subject } \\
\text { no. }\end{array}$ & Dose $(\mu g)$ & $\begin{array}{c}\text { Time } \\
\text { (h) }\end{array}$ & & \multicolumn{5}{c}{$\begin{array}{c}\text { \% of dose recovered in: } \\
\text { Urine }\end{array}$} & Fadioactivity \\
& & & $\begin{array}{c}\text { Free } \\
\text { recovered }\end{array}$ & $\begin{array}{c}\text { Conjugated } \\
\text { terbutaline }\end{array}$ & Unknown * \\
5 & $100(50 \mu \mathrm{Ci})$ & 120 & $84.7[68]$ & 56.5 & 4.0 & 24.2 & 3.1 \\
6 & $100(50 \mu \mathrm{Ci})$ & 94 & $78.4[68]$ & 60.4 & 11.1 & 6.9 & 2.2 \\
7 & $100(50 \mu \mathrm{Ci})$ & 91 & $85.7[67]$ & 52.1 & 19.4 & 14.2 & -
\end{tabular}

*By difference.

[ ] \% dose recovered in 24 hours. 


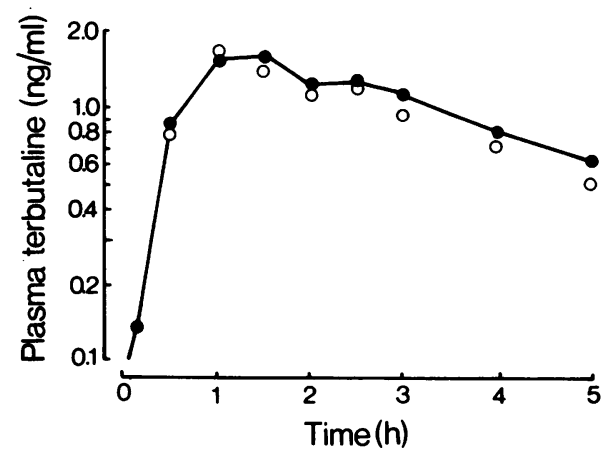

Fig. 4 Radioactivity in plasma following intragastric administration of $\left[{ }^{3} \mathrm{H}\right]$-terbutaline in the dog $(4 \mu \mathrm{g} / \mathrm{kg}$; conscious $\operatorname{dog} 4)$. (๑), total radioactivity; (0), free terbutaline.

In the conscious dog following intragastric administration peak plasma levels of radioactivity were achieved between 1 and $2 \mathrm{~h}$ (Figure 4). Initially, the radioactivity was almost entirely free terbutaline $(1.6 \mathrm{ng} / \mathrm{ml})$ and at later times $(4-5 \mathrm{~h})$ the unchanged drug still accounted for $80 \%$ of the activity. No increase in heart rate was detected at any time.

Quantitative analysis of samples from two of the dogs which received the intraduodenal dose and the conscious dog which received the intragastric dose showed that unchanged drug represented almost all of the radioactivity in urine (Table 4).

In one dog bile was collected for $2 \mathrm{~h}$ during which time $0.12 \%$ of the dose was excreted (Table 4).

\section{Intravenous administration to dogs}

Doses ranging from $2.3-18.65 \mu \mathrm{g} / \mathrm{kg}$ administered intravenously to three dogs produced only modest increases in heart rate (17-35 beats/min above base line) although concentrations of terbutaline in excess of $300 \mathrm{ng} / \mathrm{ml}$ were achieved in the dog receiving the largest dose (Table 5).

Extraction of plasma samples showed that most of the radioactivity was present as unchanged terbutaline (Table 5). This was confirmed in dog 7 where acid hydrolysis did not increase the yield of unchanged drug (Table 5).

The increases in heart rate observed are shown in Table 6 and it can be seen that peak plasma levels of free terbutaline did not correspond well with the heartrate response, although at later times the two parameters declined roughly in parallel. Nevertheless, at all times, a considerable interindividual variability in responsiveness is seen.

Urine from four dogs given intravenous terbutaline was analysed. From 16.9-46.6\% of the dose of radioactivity was excreted in 2-4 hours (Table 6). In three dogs biles was collected for $2 \mathrm{~h}$ and less than $0.2 \%$ of the dose was eliminated by this route.

Extraction of urine samples before and after hydrolysis showed that unchanged terbutaline was the major radioactive compound present. Small amounts of conjugated terbutaline were also present since hydrolysis increased the yield of extractable terbutaline.

\section{Discussion}

The limited pharmacological data obtained in these studies indicate a relative lack of chronotropic activity of terbutaline in keeping with its known $\beta_{2}$ selectivity (Bergman et al., 1969) regardless of the route of administration.

The sulphate conjugate of terbutaline was the only metabolite identified in plasma or urine from humans or dogs given the drug either orally or intravenously. However, a small percentage of

Table 4 Excretion of metabolites following intraduodenal (dogs 1-3) or intragastric (dog 4) administration of $\left[{ }^{3} \mathrm{H}\right]$-terbutaline to dogs

\begin{tabular}{|c|c|c|c|c|c|c|}
\hline \multirow{3}{*}{$\begin{array}{l}\text { Dog } \\
\text { no. }\end{array}$} & \multirow[t]{3}{*}{ Dose (mg/kg) } & \multirow{3}{*}{$\underset{\text { (h) }}{\text { Time }}$} & \multicolumn{4}{|c|}{ \% of dose recovered in: } \\
\hline & & & Bile & & Urine & \\
\hline & & & & $\begin{array}{c}\text { Total } \\
\text { radioactivity }\end{array}$ & $\begin{array}{c}\text { Free } \\
\text { terbutaline }\end{array}$ & $\begin{array}{l}\text { Conjugated } \\
\text { terbutaline }\end{array}$ \\
\hline 1 & $2.0(66 \mu \mathrm{Ci})$ & 2.0 & 0.12 & 0 & - & - \\
\hline 2 & $2.0(52 \mu \mathrm{Ci})$ & 6.0 & - & 28.6 & 32.4 & - \\
\hline 3 & $2.0(110 \mu \mathrm{Ci})$ & 8.0 & - & 27.3 & 26.4 & 0 \\
\hline 4 & $0.004(271 \mu \mathrm{Ci})$ & $\begin{array}{l}0-5 \\
24\end{array}$ & - & $\begin{array}{l}39.9 \\
58.7\end{array}$ & $\begin{array}{l}39.0 \\
57.3\end{array}$ & $\begin{array}{l}\mathbf{0} \\
\mathbf{0}\end{array}$ \\
\hline
\end{tabular}


Table 5 Plasma radioactivity after intravenous administration of $\left[{ }^{3} \mathrm{H}\right]$-terbutaline to dogs

\begin{tabular}{|c|c|c|c|c|}
\hline $\begin{array}{c}\text { Dog no. } \\
\text { (dose } \mu g / k g \text { ) }\end{array}$ & $\underset{(\min )}{T i m e}$ & $\begin{array}{l}\text { Total radioactivity } \\
\text { expressed as equivalent } \\
\text { terbutaline (ng/ml) }\end{array}$ & $\begin{array}{l}\text { Unchanged } \\
\text { terbutaline } \\
\text { (ng/ml) }\end{array}$ & $\begin{array}{c}\text { Increase in } \\
\text { heart rate } \\
\text { (beats/min) }\end{array}$ \\
\hline $6(18.65)$ & $\begin{array}{c}0.25 \\
0.50 \\
0.83 \\
1.18 \\
1.58 \\
2.0 \\
4.0 \\
6.0 \\
10.0 \\
15.0 \\
30.0 \\
60.0 \\
90.0 \\
120.0\end{array}$ & $\begin{array}{c}340.9 \\
121.5 \\
112.4 \\
106.1 \\
83.8 \\
84.9 \\
47.5 \\
35.7 \\
25.3 \\
19.3 \\
13.1 \\
10.1 \\
7.53 \\
6.01\end{array}$ & $\begin{array}{r}371.5 \\
129.8 \\
108.5 \\
94.0 \\
64.6 \\
74.8 \\
47.2 \\
35.8 \\
25.8 \\
22.3 \\
12.9 \\
8.7 \\
5.1 \\
4.8\end{array}$ & $\begin{array}{r}20 \\
12 \\
8 \\
8 \\
0\end{array}$ \\
\hline $7(2.5)$ & $\begin{array}{c}0.12 \\
0.50 \\
1.0 \\
1.38 \\
2.0 \\
5.0 \\
10.0 \\
15.5 \\
30.0 \\
60.0 \\
90.0 \\
120.0\end{array}$ & $\begin{array}{r}62.7 \\
18.8 \\
12.8 \\
9.9 \\
12.4 \\
6.9 \\
3.5 \\
4.1 \\
2.1 \\
1.4 \\
0.9 \\
0.8\end{array}$ & $\begin{array}{l}- \\
\overline{14.3}(15.0)^{*} \\
- \\
- \\
\overline{4} \\
4.2(4.4)^{*} \\
\overline{1.8} \\
1.1(1.0)^{*} \\
0.8 \\
0.7(0.6)^{*}\end{array}$ & $\begin{array}{r}17 \\
17 \\
14 \\
8 \\
5\end{array}$ \\
\hline $8(2.5)$ & $\begin{array}{c}0.50 \\
1.0 \\
2.0 \\
5.0 \\
10.0 \\
30.0 \\
60.0 \\
90.0 \\
120.0 \\
225.0\end{array}$ & \begin{tabular}{r|}
15.6 \\
11.5 \\
8.8 \\
6.3 \\
4.8 \\
2.6 \\
1.8 \\
1.4 \\
0.9 \\
0.7
\end{tabular} & $\begin{array}{l}14.1 \\
\overline{8} \\
- \\
\overline{2} \\
2.6 \\
- \\
- \\
\overline{0} \\
0.6\end{array}$ & $\begin{array}{r}35 \\
35 \\
35 \\
35 \\
30 \\
20 \\
15 \\
5 \\
0 \\
-\end{array}$ \\
\hline
\end{tabular}

Table 6 Metabolites in urine after intravenous administration of $\left[{ }^{3} \mathrm{H}\right]$ terbutaline to dogs

\begin{tabular}{|c|c|c|c|c|c|c|}
\hline \multirow[t]{3}{*}{ Dog no. } & \multirow[t]{3}{*}{ Dose $(\mu g / k g)$} & \multirow{3}{*}{$\underset{(h)}{\text { Time }}$} & \multicolumn{4}{|c|}{$\%$ of dose recovered in: } \\
\hline & & & \multirow{2}{*}{$\begin{array}{c}\text { Bile } \\
\text { Total } \\
\text { radioactivity }\end{array}$} & \multicolumn{3}{|c|}{ Urine } \\
\hline & & & & $\begin{array}{c}\text { Total } \\
\text { radioactivity }\end{array}$ & $\begin{array}{c}\text { Free } \\
\text { terbutaline }\end{array}$ & $\begin{array}{l}\text { Conjugated } \\
\text { terbutaline }\end{array}$ \\
\hline 5 & $2.3(41 \mu \mathrm{Ci})$ & 2 & 0.11 & 21.5 & 20.0 & 0.5 \\
\hline 6 & $18.65(1190 \mu \mathrm{Ci})$ & 2 & 0.06 & 16.9 & 18.5 & 0.0 \\
\hline 7 & $2.5(98 \mu \mathrm{Ci})$ & 2 & 0.19 & 46.4 & 48.2 & 0.0 \\
\hline 8 & $2.5(100 \mu \mathrm{Ci})$ & 4 & - & 35.6 & 34.3 & 0.0 \\
\hline
\end{tabular}

"By difference following extraction after acid hydrolysis. 
radioactivity remained unidentified in most of the studies.

In man the metabolism was dependent upon the route of administration. After intravenous dosing unchanged drug accounted for most of the radioactivity in plasma. More than $80 \%$ of the dose was excreted in urine, largely (68\%) as terbutaline with only $14 \%$ as the sulphate conjugate. Only $2-3 \%$ of the dose was excreted in faeces. In contrast, after oral dosing an average of $47 \%$ of the dose of radioactivity was recovered in faeces as unchanged drug indicating that terbutaline is incompletely absorbed. Less than $15 \%$ of the plasma radioactivity was unchanged terbutaline and of the radioactivityy excreted in urine, the major part $(70 \%)$ was a conjugate of terbutaline. These data are largely in agreement with those of Nilsson, Persson \& Tegnér (1972).

In dogs the route of administration did not greatly influence metabolism. In plasma and urine unchanged terbutaline was the major component following intraduodenal, intragastric or intravenous administration.

It is of interest to compare the metabolism of terbutaline with isoprenaline. The metabolism of the latter drug is similar in dog and man and is dependent on the route of administration (Conolly et al., 1972). In both species more than $90 \%$ of an oral dose is conjugated with sulphate during the 'first pass' through the gut wall and the liver. Recently, we have established that the gut wall is the major site of conjugation of isoprenaline (George, Blackwell \& Davies, 1973). The same is not true for terbutaline since in the dog it is not extensively conjugated and there is little difference in metabolism whether the drug is given orally or intravenously. These differences in the metabolism of isoprenaline and terbutaline may be due to the different sulphokinases catalysing the conjugation of the two drugs.

\section{References}

BERGMAN, J., PERSSON, H. \& WETTERLIN, $K$. (1969). Two new groups of selective stimulants of adrenergic $\beta$-receptors. Experientia, 25, 899-901.

CONOLLY, M.E., DAVIES, D.S., DOLLERY, C.T., MORGAN, C.D., PATERSON, J.W. \& SANDLER, M. (1972). Metabolism of isoprenaline in dog and man. Br. J. Pharmac., 46, 458-472.

CONWAY, W.D., MINATOYA, H., LANDS, A.M. \& SKEKOSKY, J.H. (1968). Absorption and elimination profile of isoproterenol III. The metabolic fate of dl-isoproterenol-7- $\left[{ }^{3} \mathrm{H}\right]$ in the dog. J. Pharm. Sci., 57, 1135-1141.

FORMGREN, H. (1970). A clinical comparison of the effects of oral terbutaline and orciprenaline. Scand. $J$. Resp. Dis., 51, 195-202.
The comparison is more interesting in man. After intravenous doses no conjugate of isoprenaline was found in urine suggesting that the human liver does not readily carry out this reaction. This supports the contention that, as had been demonstrated in dogs, oral isoprenaline is conjugated in the wall of the intestine.

A small percentage (14\%) of intravenous terbutaline was excreted as a conjugate in urine suggesting that conjugation could have occurred in the liver. Although a higher percentage $(70 \%)$ of the drug in urine was conjugated following oral dosing this may not necessarily be due to gut wall metabolism. Since orally administered drug enters the systemic circulation via the hepatic portal system, the higher degree of conjugation could result from 'first pass' metabolism in the liver. In preliminary studies with monkeys, which conjugate approximately $70 \%$ of orally absorbed terbutaline, we have been unable to demonstrate a substantial 'first pass' metabolism using isolated loops of gut.

In view of these differences, it is of interest that oral therapy with terbutaline has been reported to be effective in the treatment of asthma (Formgren, 1970; Freedman, 1971; Legge, Gaddie \& Palmer, 1971 ). In our studies $25 \%$ of orally absorbed terbutaline is excreted unchanged in urine, whereas, after isoprenaline, which is ineffective orally (Gay \& Long, 1949), less than $10 \%$ was excreted in urine. Thus oral terbutaline, although poorly absorbed in comparison with isoprenaline, is a more effective bronchodilator than the latter drug taken by mouth. This may be due to a lesser 'first pass' metabolism in the gut and liver.

We wish to thank Draco Laboratories of Lund, Sweden, for their financial support. M.E.C. is a Wellcome Research Fellow in Clinical Pharmacology.
FREEDMAN, B.J. (1971). Trial of new bronchodilator, terbutaline, in asthma. Br. med. J., 1, 633-636.

GAY, L.N. \& LONG, J.W. (1949). Clinical evaluation of isopropylepinephrine in the management of bronchial asthma. J. Amer. med. Ass., 139, 452-457.

GEORGE, C.F., BLACKWELL, E.W. \& DAVIES, D.S. (1974). Metabolism of isoprenaline in the intestine. $J$. Pharm. Pharmac., 00, 000-000.

GUPTA, G.N. (1968). A new approach of combustion in plastic bags for radioassay of $\left[{ }^{3} \mathrm{H}\right],\left[{ }^{14} \mathrm{C}\right]$ and $\left[{ }^{35} \mathrm{~S}\right]$ in biological, biochemical and organic materials. Microchem. J., 13, 4-19.

HERTTING, G. (1964). The fate of $\left[{ }^{3} \mathrm{H}\right]$-isoproterenol in the rat. Biochem. Pharmac., 13, 1119-1128.

LEGGE, J.S., GADDIE, J. \& PALMER, K.N.V. (1971). 
Comparison of two oral selective $\beta_{2}$-adrenergic stimulant drugs in bronchial asthma. Br. med. J., 1 , 637-639.

NILSSON, H.T., PERSSON, K. \& TEGNER, K. (1972).

The metabolism of terbutaline in man. Xenobiotica, 2, 363-373.

PERSSON, K. \& PERSSON, K. (1972). The metabolism of terbutaline in vitro by rat and human liver o-methyltransferases and monoamine oxidases. Xenobiotica, 2, 375-382.

(Received September 6, 1973) 